\title{
JISAE
}

\section{CONTEXTUAL LEARNING APPROACH AND PERFORMANCE ASSESSMENT IN MATHEMATICS LEARNING}

\author{
I Wayan Eka Mahendra \\ IKIP PGRI BALI, Jalan Seroja, Denpasar 80239 \\ eka_undiksha@yahoo.com
}

\begin{abstract}
This study aims to determine the effect of formative assessment and learning approach to the mathematics learning outcome after controlling the numerical aptitude. It was a quasi-experiment with a sample of 186 students obtained by using multistage random sampling technique with $2 \times 2$ factorial designs. The data were analyzed by ANCOVA. After controlling the numerical aptitude, the results are: the mathematics learning outcome of the students who followed a contextual approach was better than the ones who followed a conventional learning approach, the mathematics learning outcome of the students who were given a performance assessment was better than the ones who were given a conventional assessment, the interaction between the learning approach and formative assessment affected the students learning outcome for mathematics, the students who followed a contextual learning approach were more suitable to be given a performance assessment, whereas the ones who followed a conventional learning approach were more appropriate to be given a conventional assessment. Based on the research findings, junior high school teachers are suggested to improve their students learning outcome for mathematics. Then, teachers need to use a learning approach and formative assessment accurately and correctly.
\end{abstract}

Keywords: formative assessment, learning approach, mathematics learning outcome, numerical aptitude.

The results of TIMSS and PISA study showed that most students were only able to remember facts, terminologies, and laws of mathematics, but they were lack of using their knowledge to evaluate, analyze, and solve the problems of life. The causes are as follows: in classroom learning Indonesian students are generally less trained to work on problems related to their real life. Then, the instrument to assess the learning outcome is substantially less associated with the life context faced by students and facilitates students in revealing their thinking and arguing process.

Unfortunately, the mathematics learning process is currently dominated by teacher. The teacher emphasizes students to memorize concepts, especially practical formulas, which will be used to answer the questions in daily test, general test, and national examination without knowing the real benefits of the material in the everyday life. Therefore, teacher must innovate the classroom learning so that it can give an extensive chance for students to learn and improve their knowledge themselves. Students must discover and construct the knowledge in their mind themselves and give it a meaning through real experience. Learning will be meaningful for students when it is associated with real-life context. The learning approach that aims to help students see the meaning of a material they are studying by connecting the subjects of learning material with their daily life context is contextual learning approach. 
Contextual learning approach is an educational process that aims to help students see the meaning of a material they are studying by connecting it with their daily life, personal, social, and cultural circumstance (Johnson, 2012:58; Sears, 2000:2). Kalchik and Oertle (2010:1) states that contextual learning approach is a learning approach designed to connect the material content to the real situation in a specific context that interest students.

According to Berns and Ericson (2012:2), contextual learning approach is a teaching-learning conception that helps teacher connects the learning material and real-world situation; as well as motivates students to make a connection between the knowledge and its application to their lives as family member, society member, and worker so as to encourage their motivation to work hard applying their learning outcome.

In addition to the application of contextual approach, an alternative assessment is also needed to motivate students to learn. Then, it will change the paradigms that teacher is teaching and students are learning, from teacher's mathematical experience into students' mathematical experience, phenomena of teaching to test and studying for a test into accessing to learn. Lee (2000:143) states that assessment is an integral component of learning and teaching. Assessment is an action to collect information about a student or group of students to know and understand their ability (Butler, 2006:2). The alternative assessment that can be used is a performance assessment. Some experts sometimes use the term 'authentic assessment' to explain 'performance assessment', as the assessment tasks are closer to students' real life (Nitko, 1996: 243).

The Office of Technology Assessment (OTA) as cited by Elliott (1985:1) defines performance assessment is a test method that requires students to make answers or products demonstrating their knowledge and skills. The performance assessment can take various forms, such as conducting experiment, writing a long essay, and performing mathematical calculation. Nitko (1996: 239) defines that performance assessment is an assignment procedure to students in order to gather information, to the extent that students have learned. In line with Nitko, Danielson (2006: 7) reveals that performance assessment is an assessment of students learning outcome, including all assessments in writing, product, or attitude, except in the form of multiple-choice, matching, true-false, or short answer test. Open-ended essay test is one of the most common examples of performance-based assessment, but there are many other examples, i.e. artistic production, experiment in science, oral presentation, and using mathematics to solve real world problems.

The term 'aptitude' is also called 'talent'. Aptitude is an ability which is "inherent" in a person, inborn, and related to the brain structure (Semiawan, 1997: 11). Kerlinger (1990: 790) states that talent or aptitude is a potential ability to succeed in a particular field. A numeral system is part of a mathematical system. Even as a branch, the numeral system has traced the entire mathematical body. The numeral system presents at algebra, geometry, probability, statistics, and function theory. A numerical aptitude is an aptitude for general mathematical skills to work with numbers quickly and accurately (Carter, 2007: 1). The numerical aptitude in this case 
concerns the intellectual dimension which is the potential ability possessed by students in performing arithmetic operations manually, including addition, subtraction, multiplication, division, or mixed operations. This ability will allow them to develop and succeed in mathematics.

The main objective of this study is to determine the effect of formative assessment and learning approach to the mathematics learning outcome of the eighth graders of State Junior High School in the sub-district of Marga, after controlling the numerical aptitude.

\section{METHOD}

This study was conducted in State Junior High School 3 and 4 Marga, Tabanan Regency, Bali Province. It was held over four months in the first semester of the academic year 2013/2014, from July to October 2013. It used a quasi-experimental method and $2 \times 2$ factorial designs involving a sample of 186 people taken by multistage random sampling technique. The data of students' numerical aptitude were collected by using a numerical aptitude test in the form of a multiple-choice test with the reliability coefficient of 0.924 ; and the data of mathematics learning outcome were collected by using an essay test with the reliability coefficient of 0.796 . The data analysis technique used the analysis of covariance (ANACOVA). The hypotheses tested were main effect hypothesis, interaction effect hypothesis, and simple effect hypothesis.

The data analysis techniques used in this study were descriptive analysis, analysis of requirements test, i.e. normality test of data distribution, linearity test and regression direction significance test, homogeneity of variance test and alignment test of fulfilled regression line, and inferential analysis. These third analyses were conducted based on the students' numerical aptitude data and the score of students learning outcome for mathematics after applying the learning approach and formative assessment.

\section{RESEARCH FINDINGS}

1) The Mathematics Learning Outcome of the Students who Followed a Contextual Approach was Better Than the Ones who Followed a Conventional Learning Approach

Based on the statistical value of $\mathrm{F}_{\text {-test }}$, it was obtained that the $\mathrm{F}$ value $=10.769$ was higher than the $F$-table $=3.89$ with $\mathrm{db}_{\text {numerator }}=1$ and $\mathrm{db}_{\text {denominator }}=181$ in the significance level at $\alpha=0.05$; it means that $\mathrm{F}_{\text {value }}>$ $\mathrm{F}_{\text {table }}(10.769>3.89)$. Therefore, $\mathrm{H}_{0}$ was rejected and $\mathrm{H}_{\mathrm{a}}$ accepted. It proved that there was a difference in the mathematics learning outcome between the students who followed a contextual learning approach and the ones who followed a conventional learning approach after controlling the numerical aptitude. To determine the group who had a higher average score of learning outcome, it can be seen from the average corrected score of both groups. The analysis showed that the average corrected score of mathematics learning outcome in the group of students who followed a contextual learning approach was 38.35 ; meanwhile the average corrected score of mathematics 
learning outcome in the group of students who followed a conventional learning approach was 34.81. It can be concluded that the mathematics learning outcome of the students who followed a contextual learning approach was better than the ones who followed a conventional learning approach after controlling the numerical aptitude.

2) The Mathematics Learning Outcome of the Students who were Given a Performance Assessment was better than the Ones who were Given a Conventional Assessment

Based on the statistical value of $F_{\text {-test }}$, it was obtained that the $F$-value $=$ 6.217 was higher than the $F$-table $=3.89$ with $\mathrm{db}_{\text {numerator }}=1$ and $\mathrm{db}_{\text {denominator }}=$ 181 in the significance level at $\alpha=0.05$; it means that $F_{\text {value }}>F_{\text {table }}(6.217>$ 3.89); Therefore, $\mathrm{H}_{0}$ was rejected and $\mathrm{H}_{\mathrm{a}}$ accepted. It proved that there was a difference in the mathematics learning outcome between the students who were given a performance assessment and the ones who were given a conventional assessment after controlling the numerical aptitude. To determine the group who had a higher average score of learning outcome, it can be seen from the average corrected score of both groups. The analysis showed that the average corrected score of mathematics learning outcome in the group of students who was given a performance assessment was 37.93; meanwhile the average corrected score of mathematics learning outcome in the group of students who was given a conventional assessment was 35.28 . It can be concluded that the mathematics learning outcome of the students who were given a performance assessment was better than the ones who were given a conventional assessment.

3) There was an Interaction between the Learning Approach and Formative Assessment to the Mathematics Learning Outcome

From the analysis of the third hypothesis, it showed that the statistical value of $F$-test was obtained $F_{\text {value }}=46.528$ which was higher than $F_{\text {table }}=$ 3.89 with $\mathrm{db}_{\text {numerator }}=1$ and $\mathrm{db}_{\text {denominator }}=181$ in the significance level at $\alpha=$ 0.05. Therefore, $\mathrm{H}_{0}$ was rejected which meant that the interaction between the learning approach and formative assessment affected the mathematics learning outcome after controlling the numerical aptitude.

4) For the Students Given a Performance Assessment, the Mathematics Learning Outcome of the Students who Followed a Contextual Learning Approach was better than the Ones who Followed a Conventional Learning Approach

Based on the analysis of hypothesis testing, it showed that the statistical value of t-test was obtained $t_{\text {value }}=7.181$ which was higher than $\mathrm{t}_{\text {table }}=1,645$ with $\mathrm{db}=\mathrm{db}_{\text {in }}=181$ in the significance level at $\alpha=0.05$. It means that $t_{\text {value }}>t_{\text {table }}(7.181>1.645)$. Therefore, $H_{0}$ was rejected which meant for the students given a performance assessment, there was a difference in the mathematics learning outcome between the students who followed a contextual learning approach and the ones who followed a conventional learning approach after controlling the numerical aptitude. Moreover, it can be seen from the average corrected score of the two groups. 
For the students given a performance assessment, the mathematics learning outcome of the students who followed a contextual learning approach was 43.02 and the ones who followed a conventional learning approach was 32.32. It can be concluded that for the students given a performance assessment, the mathematics learning outcome of the students who followed a contextual learning approach was higher than the ones who followed a conventional learning approach after controlling the numerical aptitude.

5) For the Students Given a Conventional Assessment, the Mathematics Learning Outcome of the Students who Followed a Contextual Learning Approach was lower than the Ones who Followed a Conventional Learning Approach

Based on the analysis of hypothesis testing, it showed that the statistical value of t-test was obtained $\mathrm{t}_{\text {value }}=2.489$ which was higher than $\mathrm{t}_{\text {table }}=1.645$ with $\mathrm{db}=\mathrm{db}_{\text {in }}=181$ in the significance level at $\alpha=0.05$. It means that $t_{\text {value }}>t_{\text {table }}(2.489>1.645)$. Therefore, $H_{0}$ was rejected which meant for the students given a conventional assessment, there was a difference in the mathematics learning outcome between the students who followed a contextual learning approach and the ones who followed a conventional learning approach after controlling the numerical aptitude. Furthermore, it can be seen from the average corrected score of the two groups. For the students given a conventional assessment, the mathematics learning outcome of the students who followed a contextual learning approach was 33.59 and the ones who followed a conventional learning approach was 37.05. It can be concluded that for the students given a conventional assessment, the mathematics learning outcome of the students who followed a contextual learning approach was lower than the ones who followed a conventional learning approach after controlling the numerical aptitude.

6) For the Students Following a Contextual Learning Approach, the Mathematics Learning Outcome of the Students who were Given a Performance Assessment was better than the Ones who were Given a Conventional Assessment

Based on the analysis of hypothesis testing, it showed that the statistical value of $\mathrm{t}$-test was obtained $\mathrm{t}_{\text {value }}=9.583$ which was higher than $\mathrm{t}_{\text {table }}=1.645$ with $\mathrm{db}_{\text {in }}=181$ in the significance level at $\alpha=0.05$. It means that $t_{\text {value }}>t_{\text {table }}(9.583>1.645)$. Therefore, $H_{0}$ was rejected which meant for the students following a contextual learning approach, there was a difference in the mathematics learning outcome between the students who were given a performance assessment and the ones who were given a conventional assessment after controlling the numerical aptitude. Furthermore, it can be seen from the average corrected score of the two groups. For the students following a contextual learning approach, the mathematics learning outcome of the students who were given a performance assessment was 43.02 and the ones who were given a conventional assessment was 33.59. It can be concluded that for the students following a contextual learning approach, the mathematics learning outcome of the students who were given a 
performance assessment was better than the ones who were given a conventional assessment after controlling the numerical aptitude.

7) For the Students Following a Conventional Learning Approach, the Mathematics Learning Outcome of the Students who were Given a Performance Assessment was lower than the Ones who were Given a Conventional Assessment

Based on the analysis of hypothesis testing, it showed that the statistical value of the $\mathrm{t}$-test was obtained $\mathrm{t}_{\text {value }}=4.443$ which was higher than $\mathrm{t}_{\text {table }}=1.645$ with $\mathrm{db}_{\text {in }}=181$ in the significance level at $\alpha=0.05$. It means that $t_{\text {value }}>t_{\text {table }}(4.443>1.645)$. Therefore, $H_{0}$ was rejected which meant for the students following a conventional learning approach, there was a difference in the mathematics learning outcome between the students who were given a performance assessment and the ones who were given a conventional assessment after controlling the numerical aptitude. Moreover, it can be seen from the average corrected score of the two groups. For the students following a conventional learning approach, the mathematics learning outcome of the students who were given a performance assessment was 32.32 and the ones who were given a conventional assessment was 37.05. It can be concluded that for the students following a contextual learning approach, the mathematics learning outcome of the students who were given a performance assessment was lower than the ones who were given a conventional assessment after controlling the numerical aptitude.

\section{RESULTS AND DISCUSSIONS}

1. The Mathematics Learning Outcome of the Students who Followed a Contextual Learning Approach and Conventional Learning Approach

The mathematics learning outcome of the students who followed a contextual learning approach was higher than the ones who followed a conventional learning approach after controlling the numerical aptitude. Based on the mathematics learning of the two state junior high schools in the sub-district of Marga where this study took place, it can be concluded that the application of a contextual learning approach achieved a higher learning outcome than the application of a conventional learning approach after controlling the numerical aptitude.

Learning mathematics was not only learning the concepts, but also learning meaningfully. Meaningfulness in this case the students knew the purpose of learning mathematics. The students will learn meaningfully when the learning material was associated with the real life close to the students' daily life. Therefore, the mathematics learning process should be able to connect mathematical abstract ideas and real-world situations ever experienced or thought by the students, as mathematics appeared from the real everyday life. For example, three-dimensional and two-dimensional shapes are basically derived from concrete objects. They are formed through the abstraction process from real objects.

The mathematics learning process can be initiated with real objects, and then it gradually led to abstract concepts. It required a learning approach 
which was able to link the learning material and students' everyday life. The learning approach that can connect the learning material and students' life was a contextual learning approach. CTL supporters explained that in many ways CTL can motivate students to learn more effective than a traditional classroom approach (Kalchik and Marie Oertle, 2010: 1).

\section{The Mathematics Learning Outcome of the Students who were Given a Performance Assessment and Conventional Assessment}

Performance assessment is an assignment procedure to students in order to gather information, to the extent that students have learned. This assessment requires students to apply their knowledge and skills to demonstrate their mastery of the learning target. The performance assessment is an assessment in which teachers observe and make judgments about what students know and can do in their learning.

One of the performance assessment advantages was to motivate the students to learn. They will be trained to be able to think critically, fast, and know their strengths and weaknesses in learning. Motivation was one of the important factors that may affect the level of students learning outcome. A strong motivation to learn will make the students study hard and eventually showed in their learning outcome. The stronger was the encouragement to learn, the higher the result will be achieved. The performance assessment conducted by the teachers also had a great contribution to improve the students learning outcome.

Through a performance assessment applied in the learning process, the students felt that their assignments were really meaningful and they directly knew their level of knowledge on a problem. The advantages of a performance assessment were also supported by Al-sadaawi (2008: 1) which showed that $23 \%$ variation of students learning outcome (the post test result) was due to a performance assessment. It showed that the performance assessment had a significant contribution to the students learning outcome.

\section{The Interaction Between the Learning Approach and Formative Assessment to the Mathematics Learning Outcome}

A mathematics performance assessment is an assessment form to the mathematics assignment percentages, mathematics problem-solving skills, mathematical projects, observation, and working results (product) which describes students' ability through a process, activity, performance, or result of a reflection process done by students. The nature of a performance assessment was based on real-life. Therefore, there was a connection between the use of a performance assessment in learning and the contextual learning approach, which was equally based on the students' real life. The application of performance assessment demanded the teachers and students to do high learning activities. It can be facilitated by a contextual learning approach, as in its application it gave enough space for the students to work and experience.

Conventional learning was a usual teaching learning process conducted by the teachers in the classroom. In conventional learning, the teaching learning process was usually directed at the "information flow" or 
"transfer" of knowledge from the teachers to students. The entire concepts received by the students derived from "what the teacher says". Students were trained like a "parrot" which was smart to imitate, but difficult to create on their own. Teachers will be proud when their students were able to repeat orally most of the information contained in the textbook or given by the teacher.

In this approach, a conventional assessment in the form of paper and pencil test (standardize test) was suitable, although it had some weaknesses. The test development, especially a multiple-choice test was caused by the several advantages of system testing, such as: it can reach extensive materials, can be held in a relatively short time, and can be checked quickly. It was not surprising that multiple-choice test became a trend and it was popularly used over the years. In the conventional learning approach, a performance assessment was not given enough space in its application, as in the learning process the active participant was the teacher and not the students.

4. For the Students Given a Performance Assessment, the Mathematics Learning Outcome of the Students who followed Contextual Learning Approach and the Ones who followed Conventional Learning Approach

The application of a performance assessment depended largely on the level of teachers and students' activity during the learning process. The higher was the level of teachers and students' activity and creativity, the higher was the level of performance assessment effectiveness. Conversely, the lower was the level of teachers and students' activity and creativity, the lower was the level of performance assessment effectiveness. Moreover, it may not be able to run properly. This learning process will be achieved with a contextual learning approach. Through this approach, the learning process and its assessment were conducted together between the teachers and students. It was in line with a study by Kadir (2009: 88) which showed that the problem performance assessment was more appropriate with the cooperative learning. Then, the problem posing assessment was more suitable with the problem posing performance assessment.

Based on the explanation above, it seems that a performance assessment was less appropriate to be used in the learning process with a conventional learning approach, as it was not given enough space in its application. It was happened because the students were passive and the teachers were active in the learning process. The teachers will get difficulty in accessing the students' performance in the classroom. It resulted in what was accessed by the teachers was not optimal, so the results were also not optimal. Therefore, the performance assessment became a collection of assignments that was not meaningful for the students and teachers.

5. For the Students Given a Conventional Assessment, the Mathematics Learning Outcome of the Students who followed a Contextual Learning Approach and Conventional Learning Approach

One of the contextual learning approach components was an authentic assessment. Authentic assessment focused on assessing the process without 
overriding the results. It was based on the learning should be actually emphasized in an effort to help the students to be able to learn the material instead of focusing on the acquisition of various information at the end of learning activities. It means that the information was collected by the students during and after the learning process.

The information collection was not only from the teachers, but also it can be from peers or other people involved in learning. It was obviously not appropriate when the students' knowledge was only assessed by using a conventional assessment, as it can reduce the students' motivation and lower the students learning outcome later.

In a conventional learning approach, the indicator often used to assess the learning quality was the students learning outcome represented by the test results. The effect of this view was reinforced by the assessment form used, i.e. a conventional assessment in the form of standardized tests (paper and pencil test). The teachers even competed to transfer the learning materials to prepare their students for examination. In a conventional learning approach, the students study as if they were forced to receive information from the teachers without giving any critical reflection. This condition also made the teachers felt reluctant to conduct the learning activities focused on the students' activity to perform their skills. With this condition, a conventional assessment will be more appropriate to access student's ability, although it was not comprehensive. It was consistent with a study by Kadir (2009: 88) which showed the students' metacognition given a problem posing performance assessment was better than the ones given a problem solving assessment in a conventional learning setting.

6. For the Students Following a Contextual Learning Approach, the Mathematics Learning Outcome of the Students who were given a Performance Assessment and Conventional Assessment

Mathematics learning with a contextual learning approach happened when the students applied and experienced what was taught by referring to the real problems associated with their roles and responsibilities as the family members, community members, students, and workers. The contextual learning approach recognized that learning only occurred when students processed the new information or knowledge so that it seemed reasonable with their frame of mind. Therefore, the contextual learning approach provided greater opportunities for the students to express their ideas and information in learning according to their needs.

The learning above required an assessment of the students' mastery towards the learning material by using a more authentic way than a simple assessment which only accessed a small portion of the students' knowledge. It was not enough to use a conventional assessment that only provided a partial and momentary picture of the students' performance. With this assessment, it will not support the effectiveness of a contextual learning approach applied.

The students learned to be active, creative, exchanging opinion, making presentation, sharing information, and solving mathematical problem. However, the teacher only assessed the small fraction of students' 
performance and ability. It will obviously cause great disadvantages to the teachers and students, because it was inconsistent between the learning applied and the assessment used. It was in line with a study by Yuni Pantiwati (2010: i) which found no difference in the cognitive ability between the students who were given an authentic assessment and conventional assessment in the cooperative learning of TPS (Think Pair Share). The use of an authentic assessment had a higher and significant effect on the cognitive ability compared to the use of conventional assessment.

7. For the Students Following a Conventional Learning Approach, the Mathematics Learning Outcome of the Students who were Given a Performance Assessment and Conventional Assessment

In a conventional learning approach, teachers will be proud when their students were able to repeat orally most of the information contained in the textbook or given by the teacher. The students whose knowledge were assessed by using a conventional assessment will tend to follow the algorithmic and clear learning steps, as they generally liked to accept something which had already been available. The unusual things will be ignored. The application of a conventional assessment will make the students less creative, did not like challenges, slow in exchanging information, and less able to interact in the classroom. The students who used this model will be more appropriate with a conventional learning approach, as in this approach the students were required to receive information with little response.

The discussion above indicated that a performance assessment was less precise given to the students who followed a conventional learning approach, and thus they will be more suitable to be given a conventional assessment. The students tended to like conventional assessments, such as a multiple-choice, true false, and matching test, compared to an assignment to do something. Moreover, it was reinforced by the teachers' habit. The assessment applied by the teachers was based on the learning outcome assessment. They used a written test technique, such as a multiple-choice test. This assessment strategy tended to be a top-down doctrine from the center and due to the effect of learning applied, namely conventional learning (Wardhani, and Rumiati, 2004: 1-2). For the students following a conventional learning approach, it goes without saying that the mathematics learning outcome of the students who were given a performance assessment was lower than the ones who were given a conventional assessment after controlling the numerical aptitude.

\section{CONCLUSION}

Based on the results of hypothesis testing by using ANACOVA and then followed by a difference test after controlling the numerical aptitude, we can conclude as follows: The mathematics learning outcome of the students who followed a contextual learning approach is better than the ones who followed a conventional learning approach. Then, the mathematics 
learning outcome of the students who are given a performance assessment is higher than the ones who are given a conventional assessment. Furthermore there is an interaction between the learning approach and formative assessment to the mathematics learning outcomes. For the students who follow a contextual learning approach, they are more appropriate to be given a performance assessment. Meanwhile, for the ones who follow a conventional learning approach, it is more suitable for them to be given a conventional assessment.

In order to improve the learning process quality and mathematics learning outcome optimally, junior high school teachers are suggested to use a learning approach and formative assessment accurately and correctly.

\section{REFERENCES}

Ariesta, Indah Wahyu. "Efektivitas Pendekatan pembelajaran kontekstual Ditinjau Dari Sikap dan Kemampuan Pemecahan Masalah Matematis Siswa.” Jurnal Pendidikan Matematika, Volume 1 (4), Nopember 2012: 126-132.

Al-Sadaawi. “An Investigation of Performance-Based Assessment In Science In Saudi Primary Schools." Paper presented at the 34th IAEA Annual Conference, Cambridge UK, September, 2008.

Berns, Robert G., dan Patricia M. Erickson. "Contextual Teaching and Learning: Preparing Students for the New Economy." The Highlight, Zone Research @work. http://www. cord.org /uploaded files/nccte_highlight 05-contextual teachinglearning.pdf (diakses 2 Maret 2012).

Butler, Susan M., dan Nancy D. McMunn. Classroom Assessment. San Francisco: Jossey-Bass, 2006.

Carter, Philip. IQ and Aptitude Tests. London: Kogan Page Limited, 2007.

Danielson. "A Collection of Performance Task and Rubri." http://www.a ssesment.com/Danielson/10/4/2006 (diakses 6 Desember 2012).

Elliott, Stephen N. "Creating Meaningful Performance Assessment." Online. http://ericae.net/edo/ ED381985.htm (diakses 1 Maret 2013).

Gita, Nyoman. "Implementasi Pendekatan pembelajaran kontekstual Untuk Meningkatkan Hasil Belajar Matematika Siswa Di Sekolah Dasar." Jurnal Penelitian dan Pengembangan Pendidikan, Vol. 1(1), 2007: 2634.

Johnson, Elaine B. Contextual Teaching and Learning menjadikan Kegiatan Belajar Mengajar Mengasyikkan dan Bermakna, terjemahan Chaedar Alwasilah. Bandung: Kaifa, 2012. 
Kadir. "Meningkatkan Metakognisi Siswa Dalam Pelajaran Matematika Melalui Asesmen Kinerja Berbasis Masalah dan Model Pembelajaran." Jurnal Penelitian Pendidikan Agama dan Keagamaan, Vol. VII (3), September 2009: 88-108.

Kalchik, Stephanie dan Kathleen Marie Oertle. "The Theory and Application of Contextualized Teaching and Learning in Relation to Programs of Study and Career Pathways.” Transition Highlights, Issue 2, September 2010: 1-3.

Kerlinger, Fred N. Asas-asas Penelitian Behavioral, terjemahan Landung R. Simatupang. Yogyakarta: Gajah Mada University Press, 1990.

Lee K. Chiou. Alternative Assessment in My Mathematics Classroom. Jurong: Pearson Education Pte. Ltd., 2007.

Nitko, Anthony J. Educational Assessment of Studen. New Jersey: PrenticeHall, Inc., 1996.

Pantiwati, Yuni. "Pengaruh Jenis Asesmen Biologi dalam Pembelajaran Kooperatif TPS (Think Pair Share) terhadap Kemampuan Kognitif, Bepikir Kritis, Berpikir Kreatif, dan Kesadaran Metakognitif Siswa SMA di Kota Malang.” Disertasi, Universitas Negeri Malang, 2010.

Putra, Aditia. "Pengaruh Pendekatan Pembelajaran Kontekstual (CTL) Ditinjau Dari bakat Numerik Dalam Meningkatkan Hasil Belajar Matematika Di Kelas VIII SMP Negeri 11 Denpasar.” Jurnal Penelitian, Vol. 2 (2), 2012: 1-15.

Sears, Susan. Teaching and Learning: A Primer for Effective Instruction. Bloomington: Phi Delta Kappa Educational Foundation, 2000.

Semiawan, Conny. Perspektif Pendidikan Anak Berbakat. Jakarta: Grasindo, 1997.

Wardhani, Sri dan Rumiati. Penilaian Pembelajaran Matematika Berbasis Kompetensi. Yogyakarta: Departemen Pendidikan Nasional, 2004. 